\title{
Decreased Glucagon Receptors in Diabetic Rat Hepatocytes
}

\author{
EVIDENCE FOR REGULATION OF GLUCAGON \\ RECEPTORS BY HYPERGLUCAGONEMIA
}

\author{
Sam J. Bhathena, Nancy R. Voyles, Stewart Smith, and Lillian Recant, \\ Diabetes Research Laboratory, Veterans Administration Hospital and \\ Georgetown University, Washington, D. C. 20422
}

\begin{abstract}
A B S T RACT The effects of endogenous and exogenous hyperglucagonemia on the specific binding of glucagon to hepatocyte receptors was studied, as was the response of cAMP to glucagon. In streptozotocin diabetic rats, blood glucose and plasma glucagon increased and plasma insulin decreased as compared with controls. Insulin treatment in diabetic rats restored blood glucose and plasma glucagon toward normal and elevated plasma insulin. Specific binding of ${ }^{125}$ I-glucagon to isolated hepatocytes $\left(10^{6}\right.$ cells $)$ decreased in diabetic rats $(8.17 \pm 0.38 \%)$ compared to controls $(14.05 \pm 0.87 \%)$ and was restored by insulin treatment $(12.25 \pm 0.93 \%)$. Specific binding of ${ }^{125}$ I-insulin in controls was $7.30 \pm 10.16 \%$; it increased in diabetic rats to $12.50 \pm 0.86 \%$, and decreased in diabetic rats after insulin treatment $(9.08 \pm 0.87 \%)$. Scatchard analysis and the competition plots of the data indicate that decreased glucagon binding and increased insulin binding in diabetes were due to change in the number of receptors rather than a change in their affinity. Hepatocyte cAMP response to glucagon (0.25$5.0 \mathrm{ng} / \mathrm{ml}$ ) was almost abolished in diabetic rats and was restored with insulin treatment.

Specific glucagon binding by hepatocytes from chronically hyperglucagonemic (glucagon injected) rats was decreased $(P<0.005)$ to $8.76 \pm 0.61 \%$ compared with controls $(13.20 \pm 0.74 \%)$ and acutely hyperglucagonemic animals $(13.53 \pm 1.33 \%)$. The decreased binding was associated with a $70 \%$ decrease in hepatocyte cAMP response to glucagon compared with a normal response in acutely hyperglucagonemic rats.

These data appear to support the concept of receptor regulation by ambient hormone level. In both endog-
\end{abstract}

This study appeared in abstract form; 1977. Diabetes. 26 (Suppl. 1): 387.

Received for publication 28 June 1977 and in revised form 6 February 1978. enous and exogenous hyperglucagonemia, however, there was a disproportionately large decrease in cAMP response to glucagon compared to the decrease in glucagon binding.

\section{INTRODUCTION}

The diabetic state in both animals and man is characterized by a relative or absolute deficiency of insulin $(1,2)$. In the presence of intestinal or pancreatic sources of glucagon, diabetes is accompanied by an absolute or relative increment in plasma immunoreactive glucagon $\left(\right.$ IRG ${ }^{1}(3)$. IRG levels progressively rise as the diabetic syndrome becomes more severe, e.g., in diabetic ketoacidosis $(4,5)$, the levels of IRG may increase as much as 100-fold over normal fasting plasma levels of 40-100 $\mathrm{pg} / \mathrm{ml}$. The correction of the metabolic abnormalities of the diabetic state by insulin treatment is accompanied by a reduction in plasma IRG toward normal $(6,7)$. These changes have been documented in both experimental animals and human diabetic subjects.

A highly significant inverse correlation has been demonstrated between the circulating plasma levels of insulin (IRI) and insulin binding to specific receptors in the experimental diabetic animal $(8,9)$, as well as in the hyperinsulinemic diabetic patient (10-12). It seemed pertinent, therefore, to determine whether similar relationships existed between glucagon receptors and plasma IRG levels. The availability of a model for endogenous hyperglucagonemia, namely, isolated hepatocytes obtained from the streptozotocin diabetic rat, before and after treatment with insulin, permitted these studies to be carried out. To test this hypothesis in a more direct

${ }^{1}$ Abbreviations used in this paper: $\mathrm{B} / \mathrm{F}$, bound glucagon to free glucagon ratio; IRG, immunoreactive glucagon; IRI, immunoreactive insulin. 
manner, the effect of exogenous hyperglucagonemia upon glucagon binding in normal rats was also studied.

The observations support an inverse correlation between elevated plasma levels of IRG and specific glucagon binding under conditions of chronic, but not acute, hyperglucagonemia. Further, the alterations in glucagon binding are shown to correlate with the biological effectiveness of the glucagon molecule as measured by the formation of CAMP.

\section{METHODS}

Male Sprague-Dawley rats (Flow Laboratories, Dublin, Va.) weighing $120-150 \mathrm{~g}$ were used for all studies. Two types of studies were conducted. In the first, rats were made diabetic by injecting $85 \mathrm{mg} / \mathrm{kg}$ streptozotocin (Calbiochem, San Diego, Calif.) through the femoral vein after an overnight fast. They were allowed free access to food and water but were supplemented with $5 \%$ glucose in water for the first 2 days after injection. The animals were sacrificed 5-10 days later when their blood glucose levels rose to $>400 \mathrm{mg} / 100 \mathrm{ml}$. After 5 days, some diabetic animals were treated for an additional 5 days with subcutaneously administered isophane insulin, $5 \mathrm{U} /$ day (Eli Lilly and Co., Indianapolis, Ind.). All animals were studied in the fed state and sacrificed at approximately the same time of day. The rats were anesthetized with $100 \mathrm{mg} / \mathrm{kg}$ i.p. sodium amobarbital (Amytal, Eli Lilly and Co.), and blood was collected from the abdominal aorta into tubes containing 1,000 U Trasylol (FBA Pharmaceuticals, Inc., New York) and $10.5 \mathrm{mg}$ EDTA and hepatocytes were prepared.

In the second study, the effect of acute infusion or chronic injection of porcine pancreatic glucagon (Eli Lilly and Co.) was assessed on glucagon binding in fed normal rats.

Infusion. The rats were anesthetized by amytal, and glucagon $(2 \mathrm{mg} / 2 \mathrm{ml})$ was infused through the femoral vein over a 2-h period, using a Harvard pump (Harvard Apparatus Co. Inc., Millis, Mass.). Control animals were infused with $2 \mathrm{ml}$ saline over a 2 -h period.

Injection. The rats were injected intramuscularly with 100 $\mu$ g glucagon twice daily for 7 days. No injection was given on the day of sacrifice. The rats were anesthetized and the hepatocytes were prepared.

Blood glucose was measured by the glucose oxidase method using a protein-free filtrate. Plasma immunoreactive insulin (IRI) was measured according to Morgan and Lazarow (13), and plasma IRG was assayed according to Unger et al. (14) using antibody $30 \mathrm{~K}$. Hepatocytes were prepared by the collagenase (CLS IV, Worthington Biochemical Corp., Freehold, N. J.) digestion of liver according to Zahlten and Stratman (15) with the addition of $5 \mathrm{mg} / 100 \mathrm{ml}$ soybean trypsin inhibitor (Sigma Chemical Co., St. Louis, Mo.) (16). The viability of the cells was checked by the trypan blue exclusion technique and found to be $>95 \%$.

${ }^{125} \mathrm{I}-\mathrm{Glucag}$ on and ${ }^{125} \mathrm{I}$-insulin were prepared according to Hunter and Greenwood (17), as modified by Giorgio et al. (18), sp act $=0.20-0.4$ and $0.1-0.2 \mathrm{mCi} / \mathrm{nmol}$, respectively. Carrierfree ${ }^{125}$ I-iodine was purchased from New England Nuclear, Boston, Mass. Pancreatic porcine insulin and pancreatic porcine glucagon were gifts from Eli Lilly and Co.

The iodinated insulin preparations were demonstrated to have biological activity equivalent to unlabeled hormone as measured by $\left[{ }^{14} \mathrm{C}\right]$ glucose conversion to ${ }^{14} \mathrm{CO}_{2}$ in isolated adipose tissue $(19,20)$. The activity of ${ }^{125} \mathrm{I}$-glucagon preparations was demonstrated in isolated hepatocytes by measuring cAMP formation $(20,21)$.

To measure insulin binding, $10^{6}$ cells were incubated for 30 min at $20^{\circ} \mathrm{C}$ in a final volume of $0.2 \mathrm{ml}$ of a $0.3-\mathrm{M}$ potassium phosphate buffer, pH 7.5, containing $1 \%$ bovine serum albumin (Sigma Chemical Co.) and $0.1 \mathrm{ng}^{125} \mathrm{I}$-insulin in the presence of $0-10 \mu \mathrm{g}$ unlabeled porcine insulin. Glucagon binding was measured by incubating $10^{6}$ cells for $30 \mathrm{~min}$ at $30^{\circ} \mathrm{C}$ with $0.2 \mathrm{ng}$ ${ }^{125} \mathrm{I}$-glucagon and $0-10 \mu \mathrm{g}$ unlabeled porcine pancreatic glucagon in a final volume of $0.2 \mathrm{ml}$ of medium containing $25 \mathrm{mM}$ tris buffer, $\mathrm{pH} 7.5$, with $1 \%$ bovine serum albumin, $10 \mathrm{mM}$ glucose, $1 \mathrm{mM}$ EDTA, $1.4 \mathrm{mM}$ sodium acetate, $5.0 \mathrm{mM} \mathrm{KCl}$, $120 \mathrm{mM} \mathrm{NaCl}$, and $2.4 \mathrm{mM} \mathrm{MgSO}$. $100 \mu \mathrm{g} / \mathrm{ml} \mathrm{Bacitracin} \mathrm{(gift}$ from The Upjohn Co., Agricultural Prods MKT, Kalamazoo, Mich.) was always used in glucagon-binding studies to prevent the degradation of glucagon by hepatocytes. Samples were incubated in a Dubnoff incubator with vigorous shaking. At the end of incubation, the tubes were spun in a microfuge and the supernate was discarded. The pellet was then counted in a gamma scintillation counter. Nonspecific binding, i.e., binding in the presence of $10 \mu \mathrm{g}$ native hormone (usually $15-25 \%$ of the total binding) was subtracted from the total binding to determine the specific binding. The data were subjected to Scatchard analysis (22) to determine if there were changes in number of receptors. Additional plots were also constructed of the percent of maximum specific binding against the total concentration of hormone (tracer plus unlabeled) in the incubation media (23) to determine the apparent affinity.

To measure the degradation of glucagon by hepatocytes, the incubation was carried out as described for binding studies except that the final volume was $1.0 \mathrm{ml}$. Cells were spun down in the cold, and $1.0 \mathrm{ml}$ of medium containing $0.5 \%$ charcoal, 0.25\% Dextran T-80 (Pharmacia Fine Chemicals Div. of Pharmacia Inc., Piscataway, N. J.), 0.25\% human serum albumin (North American Biologicals, Inc., Miami, Fla.) and 1\% sheep serum (North American Biologicals, Inc.) in $0.2 \mathrm{M}$ glycine buffer ( $\mathrm{pH} \mathrm{8.8)} \mathrm{was} \mathrm{added} \mathrm{to} \mathrm{the} \mathrm{supernate.} \mathrm{The} \mathrm{tubes} \mathrm{were}$ incubated at $4^{\circ} \mathrm{C}$ for $45 \mathrm{~min}$ and spun in the cold. The supernate and pellet were counted separately. The counts precipitated by charcoal were considered intact glucagon. The ratio of counts in the supernate to the total counts determined the percent of added hormone which was degraded. To measure insulin degradation, $10 \%$ trichloroacetic acid (TCA) was used instead of the charcoal-Dextran mixture. The biological response of cells to glucagon was studied by measuring the cAMP formation in the presence of $0-10 \mathrm{ng}$ porcine glucagon/ $3.75 \times 10^{6}$ hepatocytes in a final volume of $2.0 \mathrm{ml}$ by the method described previously (21).

\section{RESULTS}

Studies involving endogenous hyperglucagonemia. Blood glucose, plasma IRI, and plasma IRG values in normal controls, streptozotocin-treated diabetic rats, and insulin-treated diabetic rats are shown in Table I. Injecting $85 \mu \mathrm{g} / \mathrm{kg}$ streptozotocin raised the level of blood sugar three-fold in 5 days. When these animals were treated with $5 \mathrm{U}$ isophane insulin/day for 5 days, the blood sugar returned to normal. Plasma IRI significantly decreased in diabetic rats, and plasma IRG increased to twice the normal level. On insulin treatment, plasma IRI increased significantly and plasma IRG decreased towards control values.

Hepatocytes obtained from diabetic rats, insulin-treated diabetics, and normal controls showed linearity for both glucagon and insulin binding as related to the number of cells $\left(25 \times 10^{4}-2.5 \times 10^{6}\right)$. Insulin binding 
TABLE I

Effect of Diabetes on Blood Glucose, Plasma Insulin, and Glucagon in Fed Rats

\begin{tabular}{lcccc}
\hline $\begin{array}{c}\text { Animal } \\
\text { preparation }\end{array}$ & $\begin{array}{c}\text { No. } \\
\text { animals }\end{array}$ & $\begin{array}{c}\text { Blood } \\
\text { glucose }\end{array}$ & Plasma IRI & Plasma IRG \\
\hline & & $m g / 100 m l$ & $\mu U / m l$ & $n g / m l$ \\
Control (C) & 35 & $128 \pm 7^{*}$ & $57.5 \pm 4.9$ & $0.13 \pm 0.02$ \\
Diabetic (D) & 33 & $401 \pm 13$ & $22.6 \pm 7.1$ & $0.34 \pm 0.05$ \\
Insulin R & & & & \\
$\quad$ diabetic & & & & \\
$($ I-R & 17 & $103 \pm 3$ & $437 \pm 79$ & $0.20 \pm 0.06$ \\
C vs. D & & $P<0.001$ & $P<0.005$ & $P<0.001$ \\
D vs. I-R & & $P<0.001$ & $P<0.001$ & $P<0.05$ \\
C vs. I-R & & NS & $P<0.001$ & $P<0.05$ \\
\hline
\end{tabular}

* Mean \pm SEM.

was maximum in all three groups at $20^{\circ} \mathrm{C}$ and $\mathrm{pH} 7.5$, whereas glucagon binding in all groups was maximum at $30^{\circ} \mathrm{C}$ and $\mathrm{pH}$ 7.6. The presence of calcium in the incubation medium decreased the glucagon binding in all three groups. Insulin and glucagon binding plateaued at $30 \mathrm{~min}$ for all groups, hence, binding was measured for a 30-min period in all studies. Fig. 1 shows the comparison between the specific binding of glucagon and insulin by the hepatocytes obtained from controls, diabetic, and insulin-treated diabetic rats. There was a $40 \%$ decrease in glucagon binding by hepatocytes from diabetic rats as compared with controls $(P<0.001)$. In contrast to glucagon binding, insulin binding was increased in diabetic rats $(P<0.05)$. Insulin treatment in-

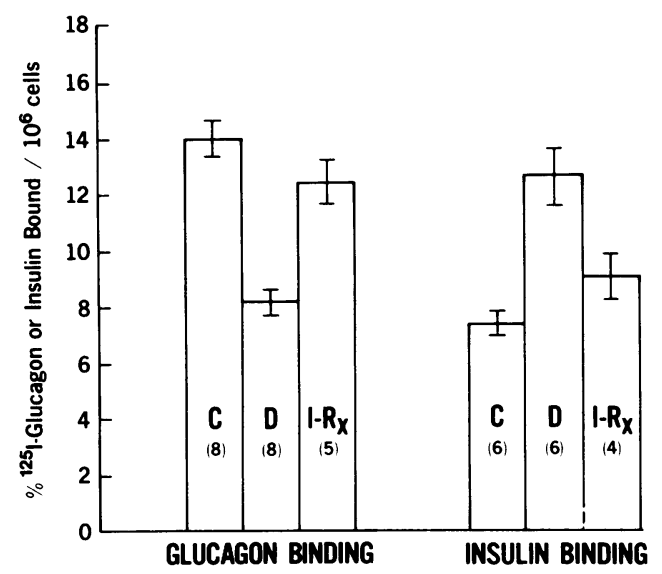

Figure 1 Specific glucagon and insulin binding to hepatocytes from control (C), streptozotocin diabetic (D), and diabetic rats treated with insulin $\left(I-R_{x}\right)$. The numbers in parentheses indicate number of rats studied. The variation shown is SEM. Binding is calculated as the percent of added tracer hormone bound by the hepatocytes. Specific binding is obtained by subtracting nonspecific binding (i.e. binding in presence of $10 \mu \mathrm{g}$ hormone) from total binding. creased glucagon binding toward normal, resulting in binding that was not significantly different from that in the controls. Insulin binding decreased appreciably on insulin treatment, however, it was still slightly, but not significantly, greater than that observed with controls.

Fig. 2A shows the Scatchard plot of glucagon binding by controls, diabetic, and insulin-treated diabetic rat hepatocytes. Both the total glucagon bound, as well as the initial bound to free $(\mathrm{B} / \mathrm{F})$ ratio, were lower in diabetic rats as compared with controls. On insulin treatment, the initial $\mathrm{B} / \mathrm{F}$ ratio increased toward the values obtained with control animals, whereas total glucagon bound increased beyond the normal levels. Since the intercept on the abscissa is taken as a measure of the number of receptors, the decreased glucagon binding in diabetic rats appears to be due to a decrease in the number of receptors. The Scatchard plot for insulintreated diabetic rats is not parallel to that of normal or untreated diabetics. It is steeper during the initial part of the curve, which suggests that there may be a change in the affinity of receptors. When the same data are plotted as percent of maximum specific binding against total glucagon present in the incubation medium (Fig. $2 \mathrm{~B})$, there is no significant difference between the three curves. This indicates that despite the suggestive affinity change in Fig. 2A, there is no significant difference in the affinity of receptors among the three groups.

Similar analyses of insulin binding to the hepatocytes from the three groups are shown in Fig. 3A and B. Fig. $3 \mathrm{~A}$ shows that the increased insulin binding by hepatocytes from diabetic rats was due to an increase in the number of receptors and that on insulin treatment, insulin binding decreased due to a decrease in the number of receptors. As seen in Fig. 3B, there was no significant difference in the affinity of hepatocytes for insulin in controls, diabetic, or insulin-treated diabetic rats.

To rule out the possibility that decreased glucagon binding in diabetic rats could have been due to factors such as increased glucagon degradation, the degradation of both insulin and glucagon by hepatocytes was examined. There was no significant difference in the amount of insulin degraded by hepatocytes (Table II) obtained from controls, diabetic, or insulin-treated diabetic rats. Degradation of glucagon by hepatocytes was also not altered in diabetes. However, there was significantly greater degradation $(P<0.05)$ of glucagon by hepatocytes from insulin-treated diabetic rats when compared with hepatocytes from either normal or untreated diabetic rats. The significance of this observation is not clear.

Since plasma IRG levels were higher in diabetic rats, it seemed pertinent to determine whether binding changes could have been due to differences in the amount of glucagon endogenously bound to the cells. The liver cells of controls and untreated diabetic rats were extracted for glucagon (24) and IRG was measured. There 
A

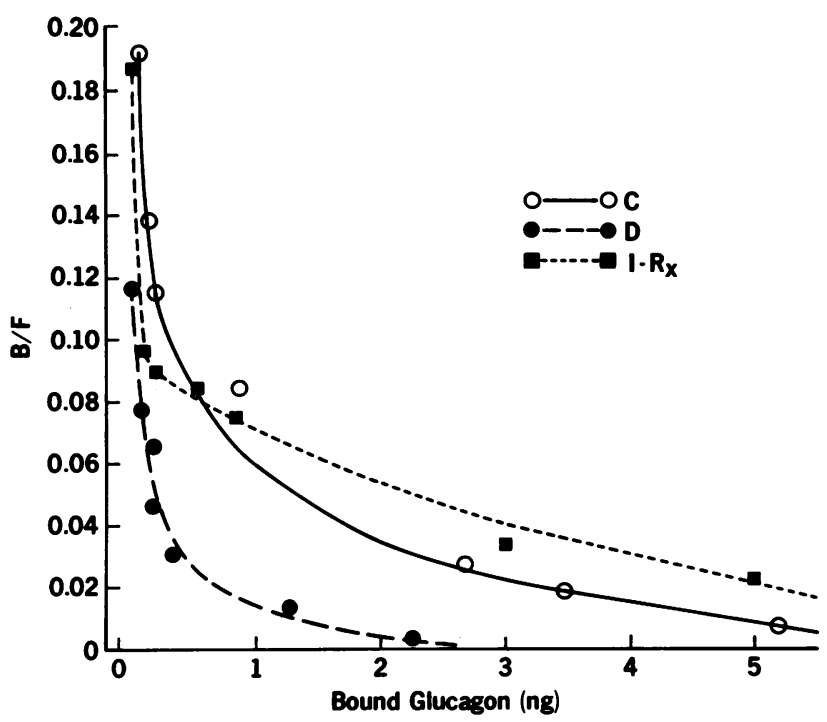

B

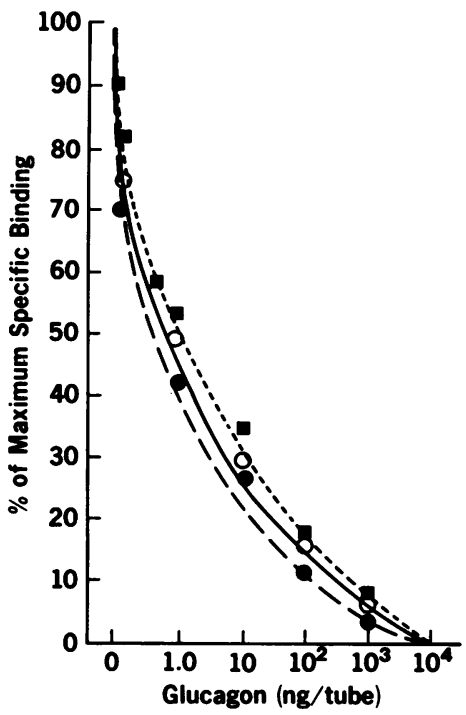

Figure 2 (A) Scatchard analysis and (B) Competition curves of glucagon binding to hepatocytes from control (C), diabetic (D), and insulin-treated diabetic rats $\left(\mathrm{I}-\mathrm{R}_{\mathrm{x}}\right)$. Each curve represents the mean of five separate experiments. In competition curves, the abscissa represents total glucagon (tracer + unlabeled glucagon) per tube in a final volume of $\mathbf{0 . 2}$ $\mathrm{ml}$. Ordinate indicates specific binding at increasing concentrations of glucagon which are calculated as the percent of that bound in the presence of tracer only, taken as $100 \%$.

were no significant differences between control and diabetic hepatocytes.

To determine whether the decreased binding of glucagon to diabetic rat hepatocytes was accompanied by a corresponding decrease in biological activity of glucagon, measurements were made of cAMP formation by the hepatocyte in response to glucagon. Since theophylline, a known blocker of cAMP phosphodiesterase
A

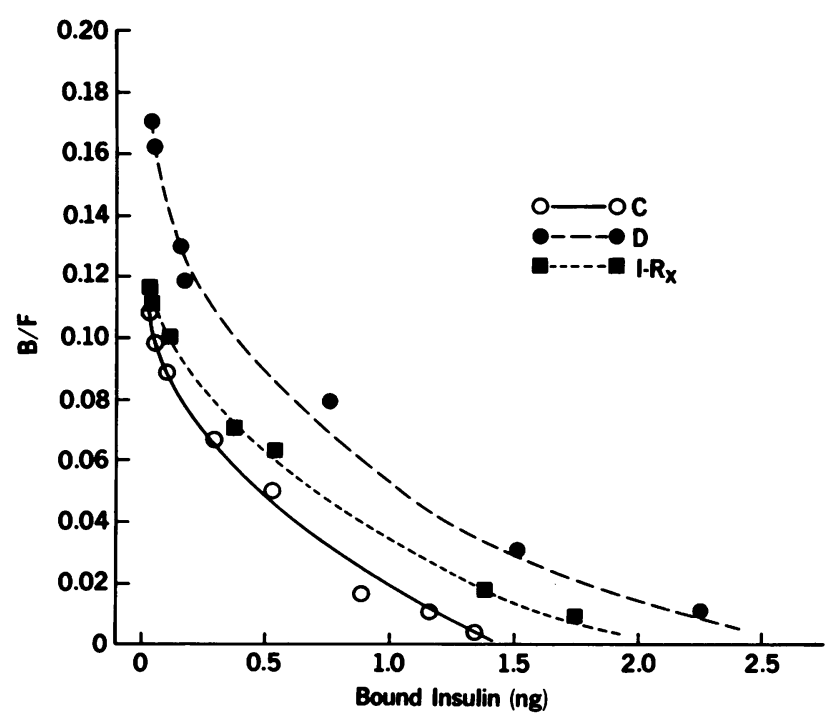

B

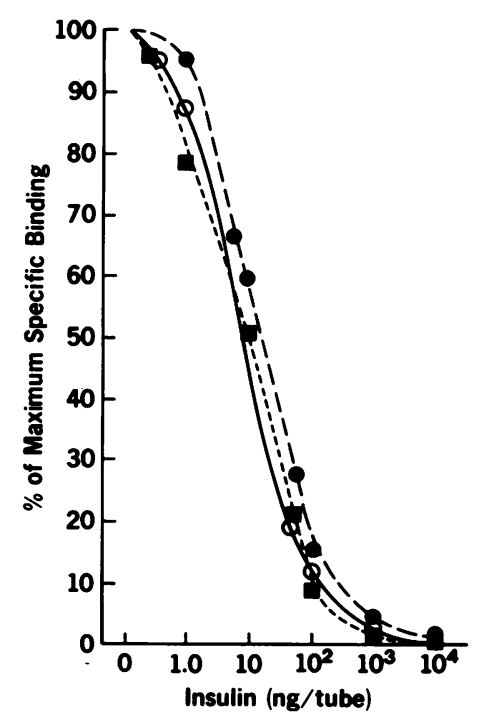

FIGURE 3 (A) Scatchard analysis and (B) Competition curves of insulin binding to hepatocytes from control (C), diabetic (D), and insulin-treated diabetic rats $\left(I-R_{x}\right)$. The curves for control and diabetic rats are the mean of four separate experiments and the curve for insulintreated rats is the mean of three separate experiments. For details, refer to Fig. 2. 
TABLE II

Effect of Diabetes on Degradation of ${ }^{125}$ I-Insulin and ${ }^{125}$ I-Glucagon by Rat Hepatocytes*

\begin{tabular}{lccc}
\hline \multicolumn{1}{c}{ Animal preparation } & $\begin{array}{c}\text { No. } \\
\text { animals }\end{array}$ & 125I-Insulin & 125I-Glucagon \\
\hline Control (C) & 4 & $1.14 \pm 0.73 \ddagger$ & $7.42 \pm 0.60$ \\
Diabetic (D) & 4 & $0.40 \pm 0.04$ & $6.06 \pm 1.86$ \\
$\begin{array}{l}\text { Insulin } R_{\mathbf{x}} \text { diabetic } \\
\quad\left(I-R_{\mathbf{x}}\right)\end{array}$ & 3 & $0.82 \pm 0.16$ & $13.45 \pm 2.25$ \\
C vs. D & & NS & NS \\
D vs. I-R & NS & $P<0.05$ \\
C vs. I-R & & NS & $P<0.05$ \\
\hline
\end{tabular}

* The percent degradation after a 30 -min incubation in the media described for binding studies of insulin and glucagon, respectively. Bacitracin was omitted.

$\ddagger$ Mean \pm SEM.

(25), was present in the incubation media, cAMP formation presumably reflects the changes in the activity of adenylate cyclase. Fig. 4 shows the cAMP responses to glucagon of hepatocytes from control, diabetic, and insulin-treated diabetic rats. Although glucagon binding in hepatocytes from diabetic rats was decreased by $40 \%$, there was essentially no increased cAMP formation in these hepatocytes in response to $10 \mathrm{ng}$ of glu-

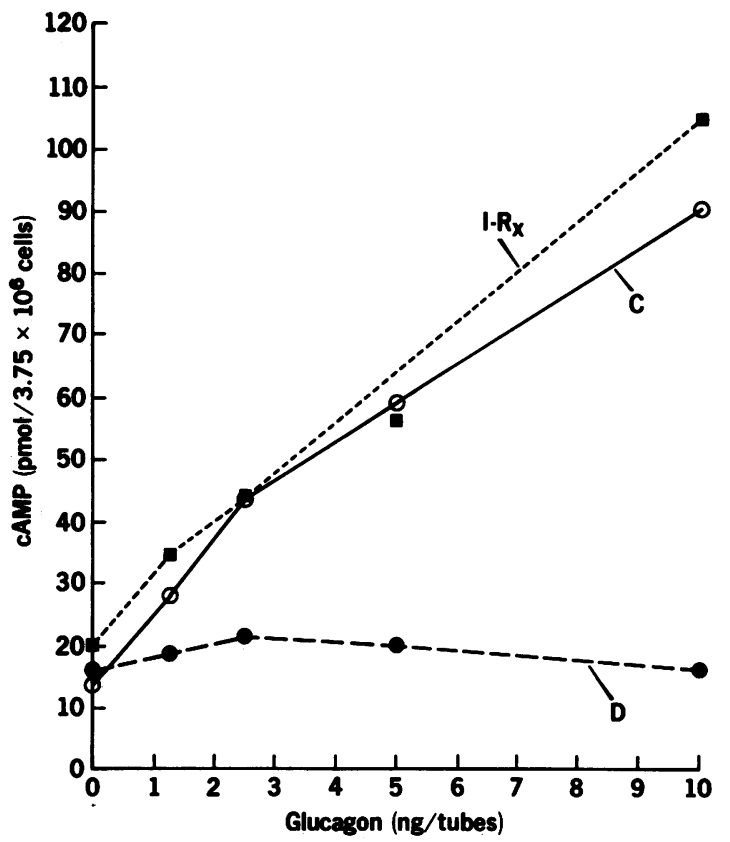

FIGURE 4 Basal- and glucagon-stimulated production of cAMP by hepatocytes of control (C), diabetic (D), and insulin-treated diabetic $\left(I-R_{x}\right)$ rats. Each point is the mean of four separate cell preparations for control and diabetic rats and of two separate preparations for insulin-treated diabetic rats. Each incubation tube had $3.75 \times 10^{6}$ cells in a final volume of $2 \mathrm{ml}$. cagon. The response to glucagon returned to normal in hepatocytes from insulin-treated diabetic rats.

Studies involving exogenous hyperglucagonemia. Table III shows blood sugar, plasma IRG, and plasma IRI levels in control and in glucagon injected and infused rats. Since there were no differences in the blood sugar, plasma IRG, and plasma IRI values between control rats infused with saline for $2 \mathrm{~h}$ and control rats injected with saline for 7 days, the two sets of controls were combined into one control group. There was no significant difference in blood sugar between the control and glucagon-injected rats, however, in rats infused with glucagon, blood sugar was elevated significantly. Plasma IRG levels were highest in the rats receiving acute infusions of glucagon, although pharmacologic elevations were also observed in rats injected with glucagon. Since a single control and a single experimental animal were studied simultaneously, all statistical comparisons were done by paired analysis.

There was a significant decrease in glucagon binding in rats injected with glucagon (Fig. 5) but not in rats infused with glucagon, though the latter group had much higher values of plasma IRG. Insulin binding was identical in all groups. There was no significant difference in the degradation of either glucagon or insulin between various groups (Table IV).

Scatchard analysis of glucagon binding (Fig. 6A) shows that decreased binding in glucagon injected rats was due to decrease in the number of receptors. The competition curves (Fig. 6B) show no change in the apparent affinity of glucagon binding in glucagon injected or infused rats. As seen in Fig. 7A and B, there was no change in either the receptor number or affinity of insulin binding between various groups.

The sensitivity of hepatocytes to glucagon, as meas-

TABLE III

Effect of Exogenous Glucagon on Blood Glucose, Plasma Insulin, and Glucagon in Fed Rats

\begin{tabular}{|c|c|c|c|c|}
\hline $\begin{array}{c}\text { Animal } \\
\text { preparation }\end{array}$ & $\begin{array}{c}\text { No. } \\
\text { animals }\end{array}$ & $\begin{array}{l}\text { Blood } \\
\text { glucose }\end{array}$ & Plasma IRI & Plasma IRG \\
\hline & & $m g / 100 \mathrm{ml}$ & $\mu U / m l$ & $n g / m l$ \\
\hline Control (C) & 12 & $130 \pm 7^{*}$ & $65.5 \pm 8.2$ & $0.16 \pm 0.02$ \\
\hline \multicolumn{5}{|l|}{ G-injected } \\
\hline (G-Inj.) & 7 & $139 \pm 11$ & $50.0 \pm 7.3$ & $3.28 \pm 0.90$ \\
\hline \multicolumn{5}{|l|}{ G-infused } \\
\hline (G-Inf.) & 5 & $164 \pm 17$ & $58.2 \pm 14.3$ & $>4.80 \ddagger$ \\
\hline C vs. G-Inj. & & NS & NS & $P<0.005$ \\
\hline C vs. G-Inf. & & $P<0.05$ & NS & $\$$ \\
\hline
\end{tabular}

* Mean \pm SEM.

‡ All values were $>4.80 \mathrm{ng} / \mathrm{ml}$. Since samples were not further diluted, the exact values, and therefore, SEM and $P$ values cannot be calculated. There was no overlap between the values in control and glucagon infused animals. Hence $P$ values appear significant. 


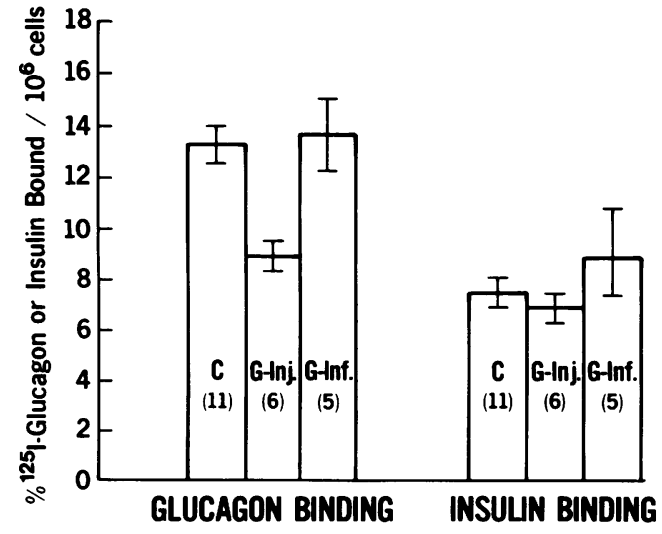

FIGURE 5 Specific glucagon and insulin binding of hepatocytes of control (C), glucagon-injected (G-Inj.), and glucagoninfused (G-Inf.) rats. Saline-injected and saline-infused rats have been combined into one control group. For details refer to Fig. 1.

ured by the production of cAMP (Fig. 8), was significantly decreased in rats injected with glucagon, but not in those infused with glucagon.

\section{DISCUSSION}

Studies of hormone receptors have been described utilizing isolated cells as well as cell membranes. In this study, isolated hepatocytes were chosen because
TABLE IV

Effect of Exogenous Glucagon on Degradation of ${ }^{125}$-Insulin and ${ }^{125}$ I-Glucagon by Rat Hepatocytes*

\begin{tabular}{lccc}
\hline \multicolumn{1}{c}{ Animal preparation } & $\begin{array}{c}\text { No. } \\
\text { animals }\end{array}$ & 125I-Insulin & 12sI-Glucagon \\
\hline Control (C) & 11 & $1.69 \pm 0.44 \ddagger$ & $7.70 \pm 1.86$ \\
G-injected (G-Inj.) & 6 & $2.06 \pm 0.85$ & $12.36 \pm 4.35$ \\
G-infused (G-Inf.) & 5 & $1.87 \pm 0.40$ & $6.82 \pm 0.68$ \\
C vs. G-Inj. & & NS & NS \\
C vs. G-Inf. & & NS & NS \\
\hline
\end{tabular}

* The percent degradation after a 30 -min incubation in the media described for binding studies of glucagon and insulin respectively. Bacitracin was omitted.

$\$$ Mean \pm SEM.

they provided reproducible data permitting correlation of the specific metabolic state of each animal with the cells prepared from that animal. It was also clear in developing this test system, that collagenase treatment had no effect upon hormone binding, since cells prepared without collagenase provided similar findings in terms of glucagon and insulin binding. It should be noted that we explored in great detail the preparation of hepatocyte cell membranes from normal and diabetic animals. Such preparations were frequently nonstandard in the sense that the concentration factor for the 5 '-nucleotidase, a membrane-marker enzyme, varied
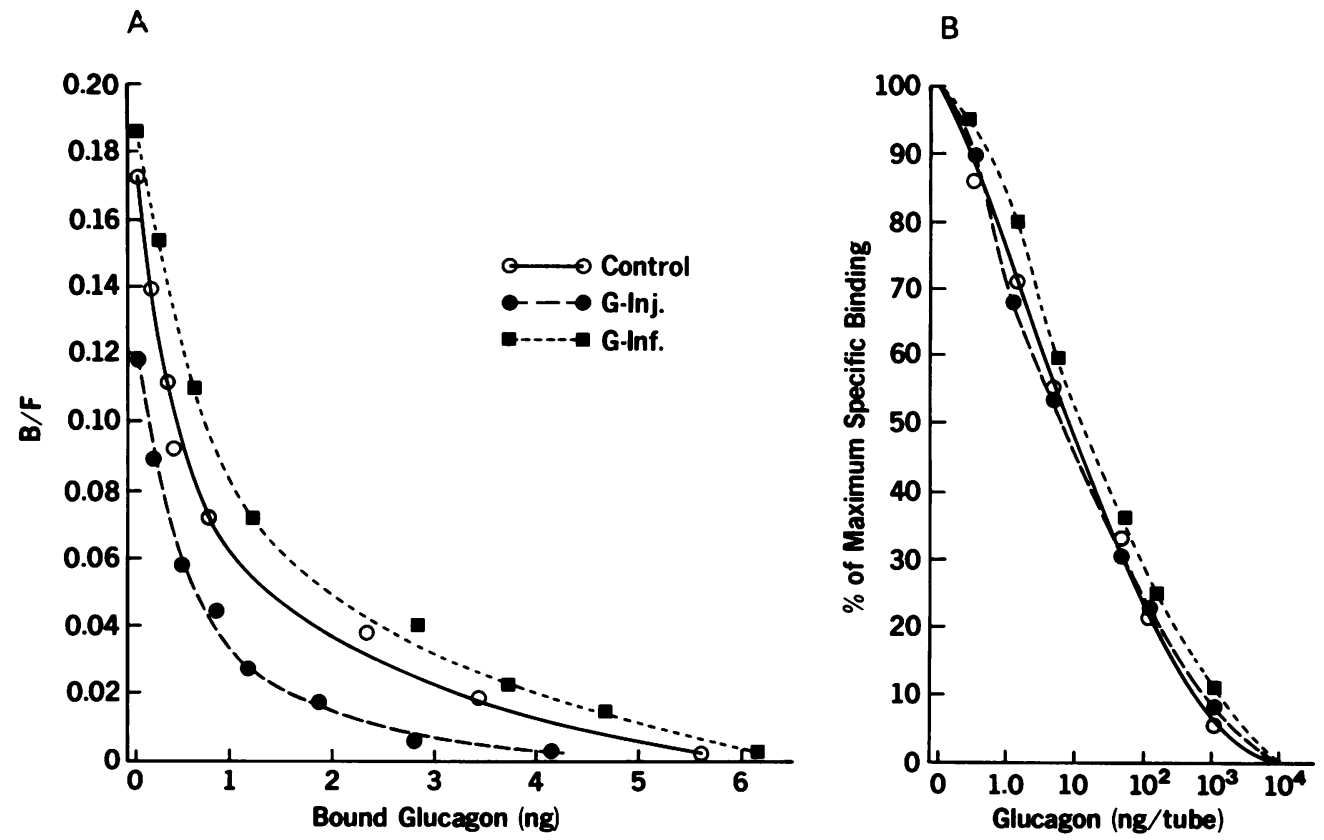

FIGURE 6 (A) Scatchard analysis and (B) competition curves of glucagon binding to hepatocytes from control (C), glucagon-injected (G-Inj.), and glucagon-infused (G-Inf.) rats. Curves for control are the mean of 11 separate experiments. The curves for glucagon-injected rats are the mean of six separate experiments, whereas the curves for glucagon-infused rats are the mean of five separate experiments. For other details, refer to Fig. 2. 
A

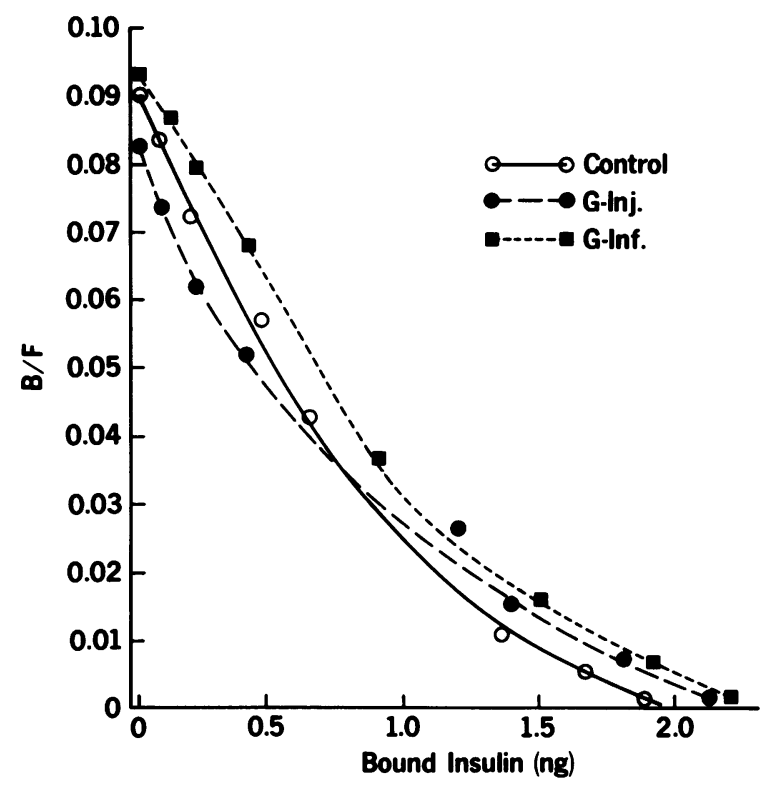

B

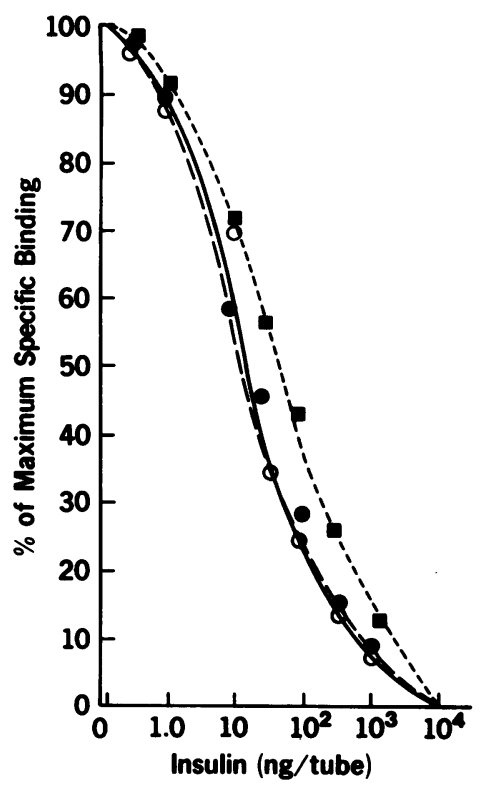

FIGURE 7 (A) Scatchard analysis and (B) competition curves of insulin binding to hepatocytes from control (C), glucagon-injected (G-Inj.), and glucagon-infused (G-Inf.) rats. Rats used are the same as in Fig. 7. For other details, refer to Fig. 2.

from 12- to 35-fold, and protein yields tended to be higher in diabetic livers. Consultation with Dr. Neville, Laboratory of Neurochemistry, National Institues of Health, revealed that the pathologic and metabolic changes induced in the liver by diabetes, insulin, and (or) glucagon treatment could significantly influence

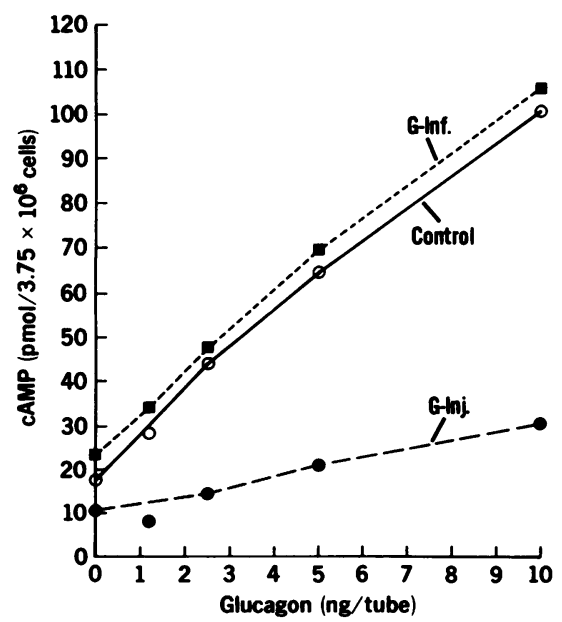

Figure 8 Basal- and glucagon-stimulated production of cAMP by hepatocytes from control (C), glucagon-injected (G-Inj.), and glucagon-infused (G-Inf.) rats. Each point is the mean of 18 separate cell preparations for control, 4 preparations for glucagon-injected rats, and 5 preparations for glucagon-infused rats. Each incubation tube had $3.75 \times 10^{6}$ cells in a final volume of $2 \mathrm{ml}$. the fractionation procedures required to obtain membranes of high quality. One example of this is found in the observation that in all membranes from diabetic animals, the 5 -nucleotidase is reduced to $50 \%$ of controls. Further, in our hands, insulin treatment restored the nucleotidase concentration towards control levels. Details of these studies will be published separately. As a result of these problems in the use of membranes, our studies were conducted with isolated hepatocytes.

In this study evidence is presented indicating that glucagon binding was significantly decreased in hepatocytes obtained from streptozotocin diabetic rats and that with insulin treatment, this binding returned to wards normal. Insulin binding, on the other hand, was increased in hepatocytes from untreated diabetics and decreased with insulin treatment. This latter observation is wholly consistent with the data of Davidson and Kaplan (8) obtained with liver plasma membranes from streptozotocin diabetic rats. However, these authors failed to observe any change in glucagon binding. This failure may be due to the fact that there is wide variation in hormone binding by membrane preparations both from individual animals and groups (26). Davidson and Kaplan (8) examined only one membrane preparation from diabetic rats for glucagon binding.

In an effort to understand why glucagon binding was decreased and insulin binding was increased in experimental diabetes, it seemed reasonable to consider the following possibilities: $(a)$ a change in the number of hormone receptors without any accompanying change in 
affinity for the hormone; $(b)$ a change in the affinity of the receptors with no corresponding change in their number; $(c)$ a change in the number and affinity of the receptors; or $(d)$ a change in the amount of degradation of either the hormone or the receptor. These possibilities were approached by subjecting the data to a Scatchard analysis and by plotting competition curves (percent maximum specific binding vs. total hormone concentration) to obtain an estimate of the apparent affinity of receptor for hormone. The Scatchard plots for glucagon binding in all animal groups were curvilinear (Fig. 2A), suggesting the existence of negative cooperativity as described by DeMeyts et al. $(27,28)$ for insulin. An additional possible interpretation would be the presence of heterogeneity of receptors or a combination of negative cooperativity and heterogeneity. Specific differentiations of these latter possibilities could not be easily obtained. Using these analyses, we found that the decrease in glucagon binding in untreated streptozotocin diabetes was most likely due to a decrease in number of glucagon receptors. The increase in insulin binding was also due to a change in the number of receptors rather than receptor affinity. This interpretation of the insulin data is in agreement with that of Davidson and Kaplan (8). After insulin treatment of diabetic animals, glucagon binding was increased towards normal and insulin binding was decreased to normal. Analysis of the glucagon-binding competition curves for cells from insulin-treated diabetic rats (Fig. $2 B)$ revealed no significant changes in affinity, but only an increase in receptor number (Fig. 2A).

The effect of insulin treatment on insulin binding also was related to a change in receptor number, namely a decrease, but not a change in affinity (Fig. 3A, B). Similar findings have been reported by Davidson and Kaplan (8) in liver plasma membranes of insulin-treated diabetic rats and by Kobayashi and Olefsky (29) in adipocytes of insulin-treated normal rats.

Since the plasma levels of IRG in diabetic rats were more than twice the levels in control rats, the possibility was raised that the hepatocyte receptors in diabetics, relative to receptors from animals with lower plasma IRG levels, might be partially saturated with glucagon. Our studies of IRG levels extracted from hepatocytes of normal and diabetic animals revealed no differences, making this an unlikely explanation for the reduced glucagon binding in diabetics. With regard to the decreased number of insulin receptors after insulin treatment, the data from several laboratories (30-33) indicate the ready dissociation of insulin from cells and membranes, thus eliminating the possibility of an endogenous saturation of receptors.

Another factor to be considered in the analysis of altered binding relates to degradation of the respective hormone. Our data provided evidence that no alteration in glucagon degradation occurred in untreated diabetic rat hepatocytes as compared to those of normal rats. Insulin degradation was unaltered in hepatocytes from either untreated or insulin-treated diabetic rats. Davidson and Kaplan (8) made similar observations on insulin degradation by plasma membranes of control and untreated diabetic rats. Our data did show increased glucagon degradation in cells from insulin-treated diabetic rats. At the present time, we have no explanation for this phenomenon, though it deserves further exploration. The fact that there was no correlation between binding of glucagon and its degradation suggests that the two processes are independent of each other.

Having accepted that the number of glucagon receptors was decreased in the diabetic state and normalized with insulin treatment, one must raise the questions of "why" and "how" this occurs. The theory of receptor "down regulation" namely decreased hormone binding by specific receptors in response to elevation of hormone levels, has been well documented for insulin $(8,20,34,35)$. Our observations with regard to glucagon binding in diabetics were consistent with a similar regulatory process in that high concentrations of plasma IRG were associated with decreased numbers of receptors, and insulin treatment of these diabetic rats was accompanied by decreased plasma IRG $(P<0.05)$ and increased numbers of glucagon receptors.

To test this hypothesis of glucagon receptor regulation by hormone levels in a more direct manner, we studied the effect of glucagon injection and infusion on receptor binding. It was clear that short-term elevation of plasma glucagon ( $2 \mathrm{~h}$ of hyperglucagonemia as seen in our glucagon-infused rats) did not decrease hepatocyte glucagon binding. On the other hand. prolonged hyperglucagonemia (normal rats injected with glucagon for $1 \mathrm{wk}$ ) decreased the glucagon receptor number. A similar time requirement for the effects of hyperinsulinism on specific receptors has been shown by Kahn et al. (36) and Gavin et al. (34).

Our studies with exogenous hyperglucagonemia strongly support, but do not absolutely prove, the hypothesis that the decrease in the receptor number is due to the regulation of glucagon receptors by the elevated plasma-glucagon level. Other factors in addition to hormone concentration and duration of exposure of the receptor to increased levels of hormone may influence or regulate binding of hormone. At least three possible factors come to mind: $(a)$ The enhanced effect of endogenous (diabetes) vs. exogenous hyperglucagonemia (injected) in decreasing receptor number may be due to direct delivery of the former to hepatic cell receptors; (b) Insulin, other than in its effect on decreasing glucagon levels, may influence receptors in as yet undefined "anabolic" fashion; and (c) Differential effects of various glucagon moieties in decreasing receptor number may depend upon the molecular species which is increased. In diabetic 
plasma and with exogenous glucagon, the increased molecular species is the $3,500-\mathrm{mol}$ wt pancreatic type glucagon. This molecule is clearly biologically active. In chronic renal disease, the major component in plasma is a $9,000-\mathrm{mol}$ wt molecule, probably proglucagon $(37,38)$. This component may not only be biologically inactive, but also may not be able to bind to the glucagon receptor. Such an effect may explain the failure to observe a decrease in glucagon receptors in the hyperglucagonemia of experimental kidney disease (39). Obviously much work remains to be done to clarify this area of glucagon receptor regulation.

What are the effects of decreased numbers of glucagon receptors in the diabetic and in glucagon injected rats? We observed that cAMP response to glucagon was markedly decreased in glucagon-injected and in diabetic rat hepatocytes. Treatment of the diabetic animals with insulin restored this response to normal. In general, these biological effects correlated with the alterations in glucagon binding. In the diabetic rat, glucagon binding was reduced by $40 \%$ and the cAMP response to glucagon was essentially abolished. Similarly, in the glucagon-injected rat, binding was decreased by $30 \%$ and glucagon-induced cAMP formation was decreased by $>70 \%$.

How can one account for the quantitative discrepancy in glucagon binding vs. cAMP formation? A number of hypotheses may be suggested: (a) Specific glucagon receptors may be heterogeneous; $20 \%$ may be true receptors capable of activating cAMP formation, whereas $80 \%$ may more properly be called acceptors in that they bind hormone but cannot activate the adenylate cyclase, and that the decrease in the number of receptors may be more pronounced in the small active receptor population rather than in the inactive acceptor population. (b) Problems in the transfer of membrane receptor signals to the enzyme may exist (40). (c) Intracellular alterations such as ATP deficiency, which may interfere with enzyme action, could occur. Such an alteration might readily be restored by insulin.

It is noteworthy that basal hepatic levels of cAMP have been reported to be elevated in diabetes (41-43) and in starvation (41, 44-46). Fouchereau-Peron et al. (47) reported that glucagon binding and cAMP response to glucagon were reduced in starvation, a situation somewhat analagous to diabetes. Thus, the mechanisms by which starved and diabetic livers develop elevations of cAMP would appear to be glucagon independent.

In conclusion, endogenous hyperglucagonemia in uncontrolled diabetes, as well as prolonged exogenous hyperglucagonemia, are associated with a decrease in the number of glucagon receptors and impaired cAMP response to glucagon. If one were to reason teleologically, the decrease in glucagon receptors and the marked decrease in the biological effect of glucagon in diabetes could provide a mechanism for reducing the excessive gluconeogenesis and hyperglycemia associated with the diabetic state.

\section{ACKNOWLEDGMENTS}

This research was supported by the Veterans Administration and National Institute of Health grant RO1 AM 19610 from the National Institute of Arthritis, Metabolism and Digestive Diseases.

\section{REFERENCES}

1. Perley, M., and D. M. Kipnis. 1966. Plasma insulin responses to glucose and tolbutamide of normal weight and obese diabetics and nondiabetic subjects. Diabetes. 15: $867-874$.

2. Parker, M. L., R. S. Pildes, K. L. Chao, M. Cornblath, and D. M. Kipnis. 1968. Juvenile diabetes mellitus, a deficiency in insulin. Diabetes. 17: 27-32.

3. Unger, R. H., E. Aguilar-Parada, W. A. Muller, and A. M. Eisentraut. 1970. Studies of pancreatic alpha cell function in normal and diabetic subjects. J. Clin. Invest. 49: $837-848$.

4. Muller, W. A., G. R. Faloona, and R. H. Unger. 1973. Hyperglucagonemia in diabetic ketoacidosis, its prevalence and significance. Am. J. Med. 54: 52-57.

5. Unger, R. H., and L. Orci. 1976. Physiology and pathophysiology of glucagon. Physiol. Rev. 56: 778-826.

6. Braaten, J. T., G. R. Faloona, and R. H. Unger. 1974. The effect of insulin on the alpha cell response to hyperglycemia in long standing alloxan diabetes. J. Clin. Invest. 53: 1017-1021.

7. Raskin, P., I. Aydin, and R. H. Unger. 1976. The effect of insulin on the exaggerated glucagon response to arginine stimulation in diabetes mellitus. Diabetes. 25: 227-229.

8. Davidson, M. B., and S. A. Kaplan. 1977. Increased insulin binding by hepatic plasma membranes from diabetic rats. Normalization by insulin therapy. J. Clin. Invest. 59: $22-30$.

9. Hepp, K. D., J. Langley, M. J. VonFuncke, R. Renner, and W. Kemmler. 1975. Increased insulin binding capacity of liver membranes from diabetic chinese hamsters. Nature (Lond.). 258: 154

10. Olefsky, J. M., and G. M. Reaven. 1974. Decreased insulin binding to lymphocytes from diabetic patients. J. Clin. Invest. 54: 1323-1328.

11. Goldstein, S., M. Blecher, R. Binder, P. V. Perrino, and L. Recant. 1975. Hormone Receptors 5. Binding of glucagon and insulin to human circulating mononuclear cells in diabetes mellitus. Endocrinol. Res. Commun. 2: 367376.

12. Flier, J. S., C. R. Kahn, J. Roth, and R. S. Bar. 1975. Antibodies that impair insulin receptor binding in an unusual diabetic syndrome with severe insulin resistance. Science (Wash. D. C.). 190: 63-65.

13. Morgan, C. R., and A. Lazarow. 1963. Immunoassay of insulin: two antibody system. Diabetes. 12: 115-126.

14. Unger, R. H., A. M. Eisentraut, and M. S. McCall. 1959. Glucagon antibodies and immunoassay for glucagon. Proc. Soc. Exp. Biol. Med. 120: 621-623.

15. Zahlten, R. N., and F. W. Stratman. 1943. The isolation of hormone-sensitive rat hepatocytes by a modified enzymatic technique. Arch. Biochem. Biophys. 163: $600-608$. 
16. Crane, L. J., and D. L. Miller. 1974. Synthesis and secretion of fibrinogen and albumin by isolated rat hepatocytes. Biochem. Biophys. Res. Commun. 60: 1269-1277.

17. Hunter, W. M., and F. C. Greenwood. 1962. Preparation of Iodine-131 labelled human growth hormone of high specific activity. Nature (Lond.). 194: 495-496.

18. Giorgio, N. A., C. B. Johnson, and M. Blecher. 1974. Hormone Receptors III. Properties of glucagon-binding proteins isolated from liver plasma membranes. J. Biol. Chem. 249: 428-437.

19. Freychet, P., J. Roth, and D. M. Neville, Jr. 1971. Monoiodo insulin: Demonstration of its biological activity and binding to fat cells and liver membranes. Biochem. Biophys. Res. Commun. 43: 400-408.

20. Freychet, P. 1976. Interactions of polypeptide hormones with cell membrane specific receptors: studies with insulin and glucagon. Diabetologia. 12: 83-100.

21. Recant, L., P. V. Perrino, S. J. Bhathena, D. N. Danforth, and R. Lavine. 1976. Plasma immunoreactive glucagon fractions in four cases of glucagonoma: Increased "Large glucagon-immunoreactivity". Diabetologia. 12: 319-326.

22. Scatchard, G. 1949. The attractions of proteins for small molecules and ions. Ann. N. Y. Acad. Sci. 51: 660-672.

23. Bhathena, S. J., S. S. Smith, N. R. Voyles, J. C. Penhos, and L. Recant. 1977. Studies on submaxillary gland immunoreactive glucagon. Biochem. Biophys. Res. Commun. 74: 1574-1581.

24. Davoren, P. R. 1962. The isolation of insulin from a single cat pancreas. Biochim. Biophys. Acta. 63: 150-153.

25. Butcher, R. W., and E. W. Sutherland. 1962. Adenosine $3^{\prime}, 5^{\prime}$-phosphate in biological material. 1. Purification and properties of cyclic $3^{\prime}, 5^{\prime}$-nucleotide phosphodiesterase and use of the enzyme to characterize adenosine $3^{\prime}, 5^{\prime}$ phosphate in human urine.J. Biol. Chem. 237: 1244-1250.

26. Sorrentino, R. N., and J. R. Florini. 1976. Variations among individual mice in binding of growth hormone and insulin to membranes from animals of different ages. Exp. Aging Res. 2: 191-205.

27. Demeyts, P., J. Roth, D. M. Neville, Jr., J. R. Gavin, III, and M. A. Lesniak. 1973. Insulin interactions with its receptors: experimental evidence for negative cooperativity. Biochem. Biophys. Res. Commun. 55: 154161.

28. DeMeyts, P., A. R. Bianco, and J. Roth. 1976. Sitesite interactions among insulin receptors, characterization of negative cooperativity. J. Biol. Chem. 251: 1877-88.

29. Kobayashi, M., and J. M. Olefsky. 1977. Effect of experimental hyperinsulinemia on insulin binding and glucose transport in isolated adipocytes. Clin. Res. 25: 394A. (Abstr.)

30. Cuatrecasas, P., B. Desbuquois, and F. Krug. 1941. Insulin-receptor interactions in liver cell membranes. Biochem. Biophys. Res. Commun. 44: 333-339.

31. Cuatrecasas, P. 1941. Properties of the insulin receptor of isolated fat cell membranes. J. Biol. Chem. 246: 7265-7274.

32. Kahn, C. R., P. Freychet, and J. Roth. 1974. Quantitative aspects of the insulin-receptor interaction in liver plasma membranes. J. Biol. Chem. 249: 2249-2257.

33. Ginsberg, B. H., C. R. Kahn, J. Roth, and P. DeMeyts. 1976. Insulin-induced dissociation of its receptor into subunits: possible molecular concomitant of negative cooperativity. Biochem. Biophys. Res. Commun. 73: 1068-1074.

34. Gavin, J. R., III, J. Roth, D. M. Neville, Jr., P. DeMeyts, and D. N. Buell. 1974. Insulin-dependent regulation of insulin receptor concentrations: a direct demonstration in cell culture. Proc. Natl. Acad. Sci. U. S. A. 71: 84-88.

35. Olefsky, J. M. 1976. Decreased insulin binding to adipocytes and circulating monocytes from obese subjects. $J$. Clin. Invest. 57: 1165-1172.

36. Kahn, C. R., D. M. Neville, Jr., and J. Roth. 1973. Insulin-receptor interaction in the obese hyperglycemic mouse. A model of insulin resistance. J. Biol. Chem. 248: 244-250.

37. Valverde, I., and M. L. Villanueva. 1976. Heterogeneity of plasma immunoreactive glucagon. Metab. Clin. Exp. 25: 1393-1395.

38. Kuku, S. F., A. Zeidler, D. S. Emmanouel, A. I. Katz, A. H. Rubenstein, N. W. Levin, and A. Tello. 1976. Heterogeneity of plasma glucagon: patterns in patients with chronic renal failure and diabetes. J. Clin. Endocrinol. Metab. 42: 173-176.

39. Soman, P. V., and P. Felig. 1977. Altered glucagon and insulin binding to hepatic receptors: cellular mechanism of glucose intolerance in uremia. Clin. Res. 25: 401A. (Abstr.)

40. Pohl, S. L. 1977. The glucagon receptor and its relationship to adenylate cyclase. Fed. Proc. 36: 2115-2118.

41. Jefferson, L. S., J. H. Exton, R. W. Butcher, E. W. Sutherland, and C. R. Park. 1968. Role of adenosine 3', $5^{\prime}$-monophosphate in the effects of insulin and antiinsulin serum on liver metabolism. J. Biol. Chem. 243: $1031-1038$.

42. Goldberg, N. D., S. B. Dietz, and A. G. O'Toole. 1969. Cyclic guanosine $3^{\prime}, 5^{\prime}$-monophosphate in mammalian tissues and urine. J. Biol. Chem. 244: 4458-4466.

43. Pilkis, S. J., J. H. Exton, R. A. Johnson, and C. R. Park. 1974. Effects of glucagon on cyclic AMP and carbohydrate metabolism in liver from diabetic rats. Biochim. Biophys. Acta. 343: 250-267.

44. Exton, J. H., G. A. Robison, E. W. Sutherland, and C. R. Park. 1971. Studies on the role of adenosine 3',5'monophosphate in the hepatic actions of glucagon and catechalamines. J. Biol. Chem. 246: 6166-6177.

45. Selawry, H., R. Gutman, G. Fink, and L. Recant. 1973. The effect of starvation on tissue adenosine $3^{\prime}, 5^{\prime}$ monophosphate levels. Biochem. Biophys. Res. Commun. 51: 198-204.

46. Garrison, J. C., and R. C. Haynes, Jr. 1973. Hormonal control of glucogenolysis and gluconeogenesis in isolated rat liver cells. J. Biol. Chem. 248: 5333-5343.

47. Fouchereau-Peron, M., F. Rancon, P. Freychet, and G. Rosselin. 1976. Effect of feeding and fasting on the early steps of glucagon action in isolated rat liver cells. Endocrinology. 98: 755-760. 